\title{
Role of Religion in Human Capital Development: Understanding Employee's Morality in Workplace in Developing Nations
}

\author{
Revd. Joseph Avwerosuoghene Agbogun* \\ Dept. of Religious Studies and Philosophy Delta state university, Abraka, Nigeria \\ *Corresponding Author \\ Revd. Joseph Avwerosuoghene Agbogun \\ Article History \\ Received: 30.11 .2019 \\ Accepted: 08.12.2019 \\ Published: 21.12.2019
}

\begin{abstract}
A Nation's developments rely largely on its social economy status, which is determined by its workplace. There is gradual change in the view of the working population in a given society, whether negatively or positively. Be it as it may, the society uses one or more of its institution to influence its members towards what can make the society work better. Morality seems to be watered down or overlooked in our society now. Lack of morality on the side of Employees has increased corruption in developing nations like Nigeria and seems there is no solution. This study employs descriptive and analytical methods in the discussion and analysis of information. It finds out that morality at workplace is neglected and people even promote their self-interest above those of these of the organization they are working for. It concludes that morality as an area of studies of religion, if emphasized will change character of workers-government and private should emphasize morality to workers to realize optimum working relationship for more productivity.
\end{abstract}

Keywords: Christianity, development, morality, workplace and Developing.

\section{INTRODUCTION}

Every organization has objectives and goals to achieve. No matter however small or large it maybe, it needs human resources to take care of the day-to-day running of affairs. These needed individuals are usually adults who have concluded moral views influenced by divine socio-cultural factors; and must come together for interaction and interpersonal relationship for the existence of the organization. As people inter-relate, there are bound to be manifestation of unacceptable moral character or others which cannot blend. A little problem in the interpersonal relationship of workers brings about huge negative effect in the productivity of the organization.

Infact, several leaderships are no longer comfortable with the moral behavior of the available workforce in Nigeria. According to Hoberman [1], there is a lot at stake for employers when it comes to making sure that the employees behave the way the company desires. Although some employees behave right but others behave in a way that proves problematic. Again the workplace composition is changing per decade, for instance, there is more woman than men, most of whom are mothers, wives and housekeepers: According to Schwartz [2], "new statistics and changes in national make-up make it obvious that the workforce of the 21 st century will be different than that of the $20^{\text {th }}$ Century. This will require the nation to develop new rules, laws, and mores to accommodate the growing diversity". This morality in workplace is not static.

Workplace in every society is diversified, majorly: public and private. The moral and ethical standard of every organization are determined by such organization and different from others with time and location. However, general/background issues of morality in workplace will be presented. For our society to be rid of corruption, crime, insecurity, terrorism and other mishaps, everyone must return to morality. To keep every organization or company at its working peak, high moral and ethical standard are needed from every worker. This work comprises of a review of morality, influencing workers' morality, right and responsibility of workers, and some ethical and unethical behaviours in workplace.

Copyright @ 2019: This is an open-access article distributed under the terms of the Creative Commons Attribution license which permits unrestricted use, distribution, and reproduction in any medium for non commercial use (NonCommercial, or CC-BY-NC) provided the original author and source are credited. 


\section{What is Morality?}

Morality means different thing to different people, but it is often used interchangeably with ethics. Accordingly, morality is a set of principles concerning right and wrong or good and bad, etc. according to moral principles. Again, it is said to be a system of moral principles follow by a particular group of people [3]. Morals are internalized. The system may not be natural rather it is set up by man for a particular reason of achieving harmony as different people socialize in an organization.

In comparative study between ethics and morals, Heberman [1] states: Although these terms are often used interchangeably by many people, they in fact have very different meanings. Ethics is the rules of conduct recognized in respect to a particular class of human actions or a particular group, culture, etc. It defines how things are according to the rules. But morals are principles or habits with respect to right and wrong conduct. It defines how things should work according to individuals' ideals and principles. Ethics are external constructs, while morals are internal beliefs that have been formed by personal experience and learning.

Though some may argue that morals cannot be changed, but if it is learned at a particular time, then it can be unlearned. When learning contexts, experiences and environment change then morals and ethics are bound to change. It can be said that morality as it relates to human behavior, attitude and character is the foundation for ethics. Since every profession has its ethics, which guides human behavior, it is this built upon the moral standard of individuals.

The preconceived moral levels of the individuals ought to be high to ensure high productivity in the society. Initiatives to increase employee work ethics are widely used by corporations and businesses in attempts to increase profitability and employee morale [4]. Several factors influence workers morality through the standard is hardly shifted on the person. To Jenkins [5] work ethics is a set of moral principles an employee uses in his job. A good worker ought to be both ethical and moral in work place. According to Heberman, ethics are defined by company practices and also by common practice. But a sense of judgement and the motivation to act rightly depend on the individual. All the institutions involve the human socialization recommend high standard of moral behavior to achieve peaceful coexistence in human and even animal society.

Everyone who wishes to behave morally must appreciate the fact that some things must pass one by. Several moral codes are unwritten, however one submits to them for society sake. According to Ejenobo [4], in pre-human period of moral history, social life even for nonhuman animals requires constraints on behavior. No group can stay together if its members make frequent unrestrained attacks on each other. With some exceptions, social animals generally either refrain altogether from attacking other members of the group or, if an attack does take place, do not make ensuring struggle a fight to death - it is over when the weaker animal shows submissive behavior. It is not difficult to see analogies here with human moral codes.

The parallels, however, go much further than this. Like humans, social animals may behave in ways that benefit other members of the group at some cost or risk to themselves. To this end, what is recommended is submission to one another at one point or issue or the other. When the submission becomes one-sided, a revolt is coming. Also, taking the cost of other group members' welfare goes a long way in maintaining societal moral codes.

Furthermore, reciprocity enhances moral behavior in the society. Reciprocity may also be a factor in food sharing among unrelated animals [4]. It is noteworthy that such reciprocity may be achieved in as much as the cost of helping another group member is not higher than the proposed gain. The continuity of such moral character also depends on the assurance of the payback from the other party - in absence of cheating. No matter the religious and cultural background of any society, it seems much compactible to study workplace morality and virtue side by side. Every well-behaved individual has a level of inner principle which controls his actions and character. Civilized societies hold to a high regard some qualities of historical antecedent with or without a rational origin.

In attempt to define virtue, Lippmann [6] said: Virtues like courage, honour, faithfulness, veracity, justice, temperance, magnanimity, and love would not be called virtues and held in high esteem if there were no difficulties about them. There are innumerable dispositions which are essential to living that no one takes the trouble to praise... It is only those actions which one cannot be depended upon to do, and yet are highly desirable, that men call virtuous. Humans recognize that a premium has to be placed upon certain qualities that a premium has to be placed upon certain qualities if men are to make the effort which is required to transcend their ordinary impulses. Virtue is that kind of conduct which is esteemed by God and public opinion, or that is less immediate part of a man's personality that is called conscience. To transcend the ordinary impulses is the common element in all virtue.

Most moral conducts remain uncommon from time immemorial till our present period. There usually difficulties for humans to behave morally right. Since right conduct is most needed in the society today, even in workplace, much is left undone about the inculcation of morality in modern society. For Plato, virtue is an inner state, is the harmony, health beauty, or strength of a soul made up of interacting parts, and right or just action that sustains or enhances inner virtue [7]. The rightness of actions depends on conflicting motives which determines one's actions. Morality is concerned with social dimension of human life and hence with principles of conduct that can have universal application. It is concerned with right conduct. 


\section{Values Integration and Reinforcement through Religion}

There must be alignment between social conduct and certain well-understood and self-consistent principles for human societies to remain stable and man's social conduct to be orderly and predictable. Ubrurhe [3] is of the view that such principles are the main goals of man's social behavior. When members of the society understand, integrate and make meaningful enough these values and principles, then there can be, to a large extent, agreement as to the direction of human behavior. The institution of Religion is saddled with this responsibility.

Obviously, Religion has indicated that values with their implications for human conduct depending on the accepted social relationship that exist between its members and their duties or other objects, including their religious faith. Thomas [8] opines that in this manner Religion creates in the individual the awareness that behaving contrary to the custom and tradition, attracts the intervention of the supernatural power, which is usually detrimental to such individual. This forces the individual in the society to pattern his behavior in agreement with the societal norms and values.

Important values of a given society are in most cases the ones placed by societal members upon one another and upon certain materials objects or phenomena. Religion helps in defining the highest values in the proper functioning of integrated systems of numerous values which should have been meaningless and unrelated. In a sense without religion inculcating influential teaching to enhance human values and behavior could be difficult. Thus, meaningful and understandable integration of values enhances consensus in human character and behavior in a given society.

Again, reinforcement of values in every society poses much stress on concerned institutions, but Religion helps a lot here. Christianity is employed in teaching and enforcing morality in some African societies, though limited. In all societies, according to Ubrurhe [3], there are clear notions of appropriate behavior. Social norms are the ideal standard of behavior - the ought - which embodied social values. The social norms are usually accompanied with both social and sacred punishments and rewards. Within the feelings of everyone, if conforms to what is expected of him and feels punished if he fails to comply. Most probably the reward and punishment arising, following our African belief, has both physical and supernatural consequences. The physical consequences according to Akintola [9] include scolding, lampoon, ostracism and excommunication while the supernatural deals specifically with the final judgment and its attendant result.

\section{Influencing Worker Morality}

Human behavior is prune to changes, either negative or positive, depending on what is associated with the individual. Heberman [1] holds that an employee morality is hard to control or effect because morals are internal and based on how someone was raised - what one person may consider to be immoral may be perfectly acceptable to someone else. However, a deliberate attempt to help someone to change his/her moral position with time can be regarded as influence. The one whose moral conduct is being influence may not be conscious about the change at the initial state.

There are universally accepted moral conducts in the society. They can be learned and unlearned. Following the submission of Miksen [10] a strong work morality or ethics requires you to focus on your daily tasks, complete them to the best of your ability and make a conscious effort to improve on your performance. Relating with oneself, working materials, and other workers have much to do with task accomplishment at workplace. The structure of a workplace and the leadership can, to a large extent affect human moral character either for good or bad. In as much as the individual worker could strive to improve his/her moral performance the organization can also make effort to have a workplace that stimulates good moral behavior.

Miksen's view on building a good with morality includes these steps: going to work on time each day; writing down one's daily tasks for each day of the week; improving daily; completing projects and tasks immediately; evaluating one's work; and developing a positive attitude. On this track the individual has the obligation to carry out his/her duty at workplace effectively and efficiently. This is an important aspect of work that enhances productivity and organization success.

Moreso, the worker has an obligation towards coworkers and work environment. It concerns judicious use and maintenance of working equipment and surrounding as well as cooperative working relationship with junior, equal and senior coworkers. Some very hardworking and goal achieving workers can be problematic in character, but an eye on them and improving their working relationship through seminar and conferences may help.

However, some scholars see workplace morality or ethics as an inner behavior that grows with someone and can be difficult to influence. In this view McFarlin submits: A work ethic is typically something ingrained within a person. There are simply put, lazy people who are impossible to motivate. However, other factors, both economical and psychological, can affect an employee's work ethic. Most people can be encouraged to greater performance and relationship, once the right motivating factors are found. This can be process of trial and error because each person may have different motivators. However, there are some basic guidelines you can follow to increase employee work ethic: expect your leadership to set a good example for workers tend to mimic authority, create a public recognition system rewarding an employee's good work morality, which can motivate others; set clear goals and milestones; monitor potential trouble makers; and create monetary award system. 
Motivating moral character in workers remains the best tool of having an inch-free working environment. When a worker is aware that the leadership is taking note of a particular wrong attitude and an action of motivation can occur, such eluding him, there is every tendency of adjustment. Many leaders fail in job definition, setting good example and monitoring worker's behavior. Creating monetary award and reward for workers especially in public service have been a thing of the past. Even in the private sector, a proprietor once said, rewarding you for what you are expected to do is no need, rather punishing for failing to work is adequate.

\section{Individual Rights and Responsibilities}

A recognition and respect for human rights and responsibilities can help to a large extent, the individual to choose right conduct at some given times. Even in workplaces humans clamour for the adequate protection of their rights, whether public or private places, the absence of which may affect the moral or immoral behavior of persons. Since morality involves the individual making moral choices in their respective workplaces, it seems logical that we have to articulate what constitutes respect for a person and her autonomy in some ways. When human interests are not in jeopardy from the society, workplace or other people, there is the tendency that making moral decisions and acting morally are naturally easy and obligatory.

In trying to answer the question of what interests of a person need to be protected in workplaces, Desjardins and McCall [11] opine: Any attempt to completely describe 'the humans good' will be controversial, of course. But there are many elements of 'the good' on which most will agree. Life is an undeniable element of human existence; protecting it would be a "no-brainer" selection. We might also say that a reasonable human life would require the minimal conditions of biological survival (food, clothing, shelter) or the very least, the real opportunity to acquire them. In a less material vein, some will argue that other specific things are essential for a truly human life: freedom from threats of severe bodily harm by others; freedom to express one's opinions' the ability to collectively determine the conditions of a shared social system; freedom to associate with others of one's choosing; and freedom to exercise religious commitments.

It is obvious that a good number of the submissions above are contained in the UN declaration of Human Rights [12]. The entire workplace must work to achieve these rights to make the work environment conducive and attractive to workers. Most humans fail to exhibit moral character under any of the above conditions, whether physical or psychological problems have ensued.

The issue of basic human rights indicates how someone could argue for a right as basic by tying it to central human interests. According to Desjardins and McCall (P.47), each of these interests is arguably constitutive of a decent human life, and violation of these interests' cuts at the core of what it means to be a person. By implication, most people who behave in an unethical or immoral manner are no longer normal in their thinking. The idea is to clear how dignity, autonomy and respect might be integrated into a picture of morality that reserves a central place for individual rights - this is respect for a person's humanity.

Protection of human rights imposes obligations on other persons, depending on the kind of right in question. There will be clear cases where human rights prohibit specific acts by others and other cases where a person's action falls outside of what one rights entitles. Working with others in an organization smoothly demands that the rights, benefits, feelings and responsibility of others be considered first before self.

Many philosophers would present a view that rights of a worker that need to be respected is corresponding to certain responsibilities or duties of others to respect these rights. Responsibilities can be seen as establishing limits on one's own actions, which set ethical limits on one's behaviours. Infact, the relationship between the employer and the employee must be understood from existing law and organization policy. This seems fair enough because both have rights to be respected and duties to each other to achieve social justice and a conducive workplace. However, in Nigeria the law is yet to protect the interest of employees, especially when the employer indulged in illegal and unethical conduct. This makes honestly, loyalty and whistle blowing to be at one's risk.

Moreso, the responsibilities of the employee are multi-dimensional in nature, unto divine laws, self and conscience, employer, the law of the land among others. Thus, discussion will include honesty, loyalty and whistle blowing. Honesty is a universally recognized ethical value. Inspite of deceptive and misleading statements that roll about like "white lie", truth remains objective and ever alive. According to Desjardins and McCall, (1996:150) dishonesty can sometimes be justified, but this typically occurs when the truth might cause someone harm. Dishonesty is much troubling and unjustified when it is done to benefit oneself at the expense of another - the responsibility to be honesty overrides one's self-interest. Dishonesty to further self-interest treats such interest as superior to the equal interest of others. It brings about double standard and jeopardizes social utility and individual liberty. Nevertheless, the temptation to be dishonest is especially strong in affairs where it can lead to great personal interest or benefits.

Obedience and loyalty to workplace superiors conflict the responsibility of whistle blowing, which involves rejecting participation at and reporting boss unethical activities. If loyalty conflicts whistle blowing, it is better the individual to consider the higher benefit to other apart from the two involved - the third party. In most cases, the whittle blower faces grace harms raging from job lost, life threat to lost friendship and resentment among co-workers. To Desjardins and McCall by blowing the whistle, "the whistleblower hopes to stop the game; but since he is neither referee nor coach, and since he blows the whistle against his own team, his act is seen as a violation of loyalty." 
Thus, the responsibility of loyalty if holds to the extreme can draw one into the depth of unethical character in workplace or make one to be a scornful object. Corporate loyalty cannot limit the moral autonomy of individuals. Loyalty to the core makes one an associate in crime and co-benefactor, thereby jeopardizing societal values. Citing Martins, Desjardins and McCall recognize that a sense of loyalty to oneself, to personal integrity, can motivate those who choose to be fair and honest in their respective workplaces. Loyalty seems to be incomplete and deceptive on the part of those who progress to involve in such character in workplace. The degree of loyalty is subjective, and it is determined by the actual behavior of co-workers involved and the corresponding benefits for self and others.

\section{Examples of Ethical Character}

Morality in workplace involves principles that when put into practice make every worker and people they are serving to behave well to enhance working relationship and productivity of the organization. Jenkins calls some ethical characters factors that come together to create a strong work ethics, which include:

Integrity: It stretches to all aspects of an employee's job. A worker with integrity fosters trusting relationships with clients, coworkers and supervisors. Coworkers value the employee's ability to give honest feedback. Clients trust an employee's advice. Supervisors rely on the employee high standard of morality; trusting him not to creating problems or steal from the organization.

Sense of Responsibility: A strong sense of responsibility affects how an employee works and the amount of tasks accomplished within a given time. When an employee feels personally responsible for any task, coming on time, putting in best effort and completing of projects to the best of ability are achieved. Otherwise the laissez-faire attitude comes to play.

Emphasis on Quality: Several employees do only minimum, just enough to keep their job intact. Employees with a strong work morality care about the quality of their work. They do their best to produce great work, not merely churn out what is needed. The employee's commitment to quality improves the company's overall quality.

Self-discipline: It takes certain level of commitment to finish your tasks every-day. Distractions and other less important jobs are bound to come. An employee with good discipline stays focused on his goals and determined to complete his assignments. These employees show a high level of dedication to the company, and always ensuring they do their part.

Sense of Teamwork: An employee with a sense of teamwork helps a team to meet its goals and deliver quality works. Infact, in most organizations, two or more workers are supposed to work together, but some employees show most of their unethical character to thwart others' effort. These employees respect their peers and help where they can, making collaborations go smoother.

Besides, needed moral behaviours may include: love or charity, hardwork, courage, happiness, patience, readiness to forgive, faithfulness, and truthfulness. There is a growing concern for issues of the lioness justice, the environment, health and safety and equality; taking diverse forms to influence the policy activities of workplace - Mahoney [13]. The Holy Bible listed them as the fruit of the Spirit in Galatians Chapter five. When an employee has warmness, polite, tolerance and able to apologize when need be, working with others become smooth.

\section{Unethical Characters}

Contrarily, many workers put up behavior that contradicts policy of the organization; stepping on the right of other workers, never ready to fulfill their tasks and responsibilities, and misusing their rights. Victoria Daft mentions the following: violation of conscience, unlawful conducts, deliberate deception, failure to honour commitments and disregard of company policy. Most employers clearly states company policies against deception, coercion and illegal activities. It is advisable to avoid untruth-worthiness, lying, and unwillingness to extend oneself to assist in department emergencies.

In addition, complaining and murmuring to coworkers cause them to distrust the boss or management promises; and remain unwilling to cooperate with requests. One unethical behavior in workplace gives birth to another. Most top management staff or boss engage in unethical activities to achieve company goals especially in business. People tend to do different atrocities to meet targets but the consequences are usually negative. It is the employer's right expects the employees to engage in ethical character but the employees also require learning from the exemplary attitudes of the leadership.

Some workers bully, insult, assault and even fight with coworkers. Injuries are inflicted psychological, physical and spiritual. Stealing in business organization takes many forms - work time being coveted for personal benefit and corrupt practices are often played down on. Taking advantage of one's workplace to market one's talent, self, goods and do anything for self-interest remain unethical. In the era of self-aggrandisement people tend to go for more than they need to sustain their life. Most civil and public servants are trying to building personal houses and driving cars above their salaries, it is. 


\section{CONCLUSION}

Having taken a survey of morality in workplace, influencing workers morality, workers right and responsibilities and some ethical and unethical characters in workplace, it becomes obvious that the venon of corruption in Nigerian society has eaten deep and it is based on self-interest. The two parties involved in workplace, either business, or any private and public organization is supposed to monitor each other's moral behavior and influence them. Most huge profit seeking individuals and organization always default morality in workplace, irrespective of class and religion.

There are much to be said of exploitation and self-interest inherent in the philosophy and practice of contemporary capitalism business and public works, as of other activities in Nigeria society. As corruption and other cheating practices increase in the society, workplace morality ought to be checked at interval to influence the behavior of workers, work owners and the government arms responsible for code of conduct. Abuses are frequently recorded with workplace providers and workers, which contribute much to the societal immorality, low productivity and underdevelopment.

Now it is clear that religion in Nigeria supposed to develop to cover changes in modern sustenance in the society. According to Mahoney [13] the issue of moral man and immoral society is a traditional concern of religion for the moral quality of life found expression not only in promoting and supporting the various public movements already identified but should spearhead a fresh concern for public responsibility and social justice throughout society. Several people fail to recognize that they ought to be socially responsible and responsive to better place the Nigerian society.

It is difficult to state whether morality in workplace is higher with the rich or poor, educated or uneducated, male or female and pointing to one religion or the other. But every individual should note that every action in workplace counts as in the home and church. Every benefit gained through unethical behavior will be accounted for, and its consequences remain far-reaching in human society development.

\section{REFERENCES}

1. Heberman, Michael, D. (2014). Morality and Ethics in the Workplace. Available @ www.google.com/blog.eskill/morality...Retrieved on 28/1/2015.

2. Schwartz, N. Felice. (1984). "Diversity in Workplace: Management Women and the New Facts of Life" in Thomas Donaldson AlGini.(ed.) Case Studies in Business Ethics. New Jersey: Prentice-Hall Inc.

3. Ubrurhe, J. O. (2000). "The Integrative and Disintegrative Functions of Religion: The Nigeria Experience". In Eniwo Samuel S. U and Micheal M. P. Adogbo (eds). Contemporary Essays in the Study of Religions. Lagos: Fairs and Exhibitions Nig. Ltd.

4. Ejenobo, T. David. (2012). Lecture Note on Ethics (REL 402) in Delta State University, Abraka.

5. Jenkins, A. (2015). "Five Factors that Demonstrate a Strong Work Ethics". In Demand Media: Hearst Newspaper. Houston: Houston chlonicles. Available @ http:// www.emeraldgrouppublishing.com/prod. Retrieved on 2/2/2019.

6. Lippmann, W. (1964). A Preface to Morals. New York: Time Incorporated.

7. Honderich, Ted (ed) (1995). The Oxford Companion to Philosophy. New York: Oxford University Press.

8. Thomas, F. O'dea. (1966). The Sociology of Religion. New Jersey: Prentice-Hall Incorporation.

9. Akintoye, A., \& Skitmore, M. (1993). Macro models of UK construction contract prices. Civil Engineering Systems, 10(4), 279299.

10. Miksen, C. (2010). How to Build a Good Work Ethics. County: Demand Media Publishing. Available @ http/l: www.emerald.

11. Desjardins, R. Joseph., \& John J. McCall. (1996). Contemporary Issues in Business Ethics. California: Wadsworth Publishing Company.

12. Mautner Thomas (ed.). (1999). Dictionary of Philosophy. Harnwasworth: Penguin Books Ltd.

13. Mahoney, J. (1990). Teaching Business Ethics in the UK, Europe and the U.S.A.: A Comparative Study. London: The Athlone Press. 